Article

\title{
Environmental Drivers of Water Use for Caatinga Woody Plant Species: Combining Remote Sensing Phenology and Sap Flow Measurements
}

\author{
Rennan A. Paloschi ${ }^{1, *(D)}$, Desirée Marques Ramos ${ }^{2}\left(\mathbb{D}\right.$, Dione J. Ventura ${ }^{1}\left(\mathbb{D}\right.$, Rodolfo Souza ${ }^{3}$, Eduardo Souza ${ }^{4} \mathbb{D}$, \\ Leonor Patrícia Cerdeira Morellato ${ }^{2}$ (D) , Rodolfo L. B. Nóbrega ${ }^{5}$ (D) , Ítalo Antônio Cotta Coutinho ${ }^{6}$, \\ Anne Verhoef ${ }^{7}$ (D), Thales Sehn Körting ${ }^{1}$ and Laura De Simone Borma ${ }^{1}$ (D)
}

check for

updates

Citation: Paloschi, R.A.; Ramos, D.M.;

Ventura, D.J.; Souza, R.; Souza, E.; Morellato, L.P.C., Nóbrega, R.L.B.; Coutinho, I.A.C.; Verhoef, A.;

Körting, S.; et al. Environmental Drivers of Water Use for Caatinga Woody Plant Species: Combining Remote Sensing Phenology and Sap Flow Measurements. Remote Sens. 2021, 13, 75. https://doi.org/ $10.3390 /$ rs13010075

Received: 31 October 2020 Accepted: 16 December 2020 Published: 28 December 2020

Publisher's Note: MDPI stays neutral with regard to jurisdictional clai$\mathrm{ms}$ in published maps and institutional affiliations.

Copyright: (C) 2020 by the authors. Licensee MDPI, Basel, Switzerland This article is an open access article distributed under the terms and conditions of the Creative Commons Attribution (CC BY) license (https:// creativecommons.org/licenses/by/ $4.0 /)$.
1 National Institute for Space Research-INPE, São José dos Campos, SP 12227-010, Brazil; dione.silva@inpe.br (D.J.V.); thales.korting@inpe.br (T.S.K.); laura.borma@inpe.br (L.D.S.B.)

2 Department of Biodiversity, São Paulo State University-UNESP, Rio Claro, Jaboticabal, SP 14884-900, Brazil; dm.ramos@unesp.br (D.M.R.); patricia.morellato@unesp.br (L.P.C.M.)

3 Department of Biological and Agricultural Engineering, Texas A\&M University, College Station, TX 77843, USA; rodolfo.souza@tamu.edu

4 Academic Unit of Serra Talhada, Federal Rural University of Pernambuco, Serra Talhada, PE 52171-900, Brazil; eduardo.ssouza@ufrpe.br

5 Department of Life Sciences, Imperial College London, Buckhurst Road, Ascot SL5 7PY, UK; r.nobrega@imperial.ac.uk

6 Department of Biology, Federal University of Ceara, Fortaleza, FL 33612, Brazil; italo.coutinho@ufc.br

7 Department of Geography and Environmental Science, The University of Reading, Reading RG6 6AR, UK; a.verhoef@reading.ac.uk

* Correspondence: rennan.paloschi@inpe.br

Abstract: We investigated the water use of Caatinga vegetation, the largest seasonally dry forest in South America. We identified and analysed the environmental phenological drivers in woody species and their relationship with transpiration. To monitor the phenological evolution, we used remote sensing indices at different spatial and temporal scales: normalized difference vegetation index (NDVI), soil adjusted vegetation index (SAVI), and green chromatic coordinate (GCC). To represent the phenology, we used the GCC extracted from in-situ automated digital camera images; indices calculated based on sensors included NDVI, SAVI and GCC from Sentinel-2A and B satellites images, and NDVI products MYD13Q1 and MOD13Q1 from a moderate-resolution imaging spectroradiometer (MODIS). Environmental drivers included continuously monitored rainfall, air temperature, soil moisture, net radiation, and vapour pressure deficit. To monitor soil water status and vegetation water use, we installed soil moisture sensors along three soil profiles and sap flow sensors for five plant species. Our study demonstrated that the near-surface GCC data played an important role in permitting individual monitoring of species, whereas the species' sap flow data correlated better with NDVI, SAVI, and GCC than with species' near-surface GCC. The wood density appeared to affect the transpiration cessation times in the dry season, given that species with the lowest wood density reach negligible values of transpiration earlier in the season than those with high woody density. Our results show that soil water availability was the main limiting factor for transpiration during more than $80 \%$ of the year, and that both the phenological response and water use are directly related to water availability when relative saturation of the soil profile fell below 0.25 .

Keywords: plant water availability; tree phenology; phenocams; Sentinel-2; MODIS

\section{Introduction}

A better understanding of plant water availability and water use is of great importance for reliable assessments of ecosystem's resilience to droughts [1]. Water availability is critical for plant growth, inducing phenological transitions and, ultimately, plant survival. 
Additionally, information on plant water balance also allows the development of more realistic soil water assessment tools and land surface models, which is a widely acknowledged requirement for research related to the plant-soil-atmosphere continuum [2].

Plant species have their own specific adaptive mechanisms to cope with droughts [3,4], which are particularly important in water-limited ecosystems such as seasonally dry tropical forests (SDTFs).

The SDTF is a unique biome that occurs in low-latitude areas of fertile soils with a low annual precipitation (ranging from about 250 to $1500 \mathrm{~mm}$ year ${ }^{-1}$ ) and a prolonged dry season that extends for five to six months [5-7]. The vegetation ranges from tall forests with closed canopies to scrublands rich in succulents and thorn-bearing plants $[7,8]$. The long water-limited period has been shown to be selective for deciduous, thorny, and succulent plant species that show a marked leaf senescence during the dry season followed by synchronous leaf flushing at the beginning of the rainy season [3,4,7-9]. The deciduity and absence of a grassy layer are important characteristics that distinguish SDTFs from other mild seasonally dry tropical biomes such as the savannas [8].

In South America, SDTFs are largely represented by the Caatinga vegetation, the predominant vegetation in northeast Brazil and located in a semi-arid region that extends over $800.000 \mathrm{~km}^{2}$ [10-12]. The climate is predominantly hot and dry, with temperatures around $26^{\circ} \mathrm{C}$ and high evapotranspiration (1500 to $2000 \mathrm{~mm}$ year ${ }^{-1}$ ) coupled with low annual rainfall $\left(400\right.$ to $800 \mathrm{~mm}_{\text {year }}{ }^{-1}$ ) [11,13]. This results in high water deficits, which are aggravated by the short rainy season that usually lasts three to five months and show erratic rain episodes $[10,13]$. The water deficit is even more severe during catastrophic severe droughts that may last three to five years [11].

For most Caatinga plant species, vegetative and reproductive structures develop exclusively during the rainy season $[3,14]$. In fact, the fast metabolic response, which is unique to the Caatinga, allows species to produce a synchronous leaf flush with the onset of the rainy season $[3,14]$.

Caatinga tree species are able to cope with long periods of drought by exhibiting different transpiration-reducing leaf morphological and photosynthetic characteristics. They also display a considerable variability in wood density and related water storage properties [3,14]. Lima et al (2012) show a high correlation between wood density and water storage in Caatinga vegetation and relate these characteristics to a seasonal phenology. Several studies have shown that high wood density and thick cell walls tend to protect plants from cavitation but, in general, both are associated with low water storage in stem tissues [15-19]. On the other hand, low wood density and thin cell walls increase the chances of cavitation but water storage may be higher and the maintenance of a high water potential may be prolonged [15-17]. The combination of these diverse plant traits produce different phenological evolutions throughout the growing season that depend on different plant water use strategies [18-20].

Eddy covariance (EC) and remote sensing (RS) techniques have been used to evaluate terrestrial environments because they allow vegetation systems to be studied at different scales: from local to global scales. The use of RS is gaining importance as satellites provide low-cost products and images with increasing spatial and temporal resolutions. The advances in technology have allowed several RS vegetation indices (VIs) to be used, improving our understanding of temporal and spatial changes in plant communities [21-23]. The direct relationship between water use and phenological response observed by RS has been used in models that seek to estimate evapotranspiration (ET) and gross primary production [24], mainly through the use of empirical or semi-empirical parameterisations, taking advantage of vegetation indices such as normalized difference vegetation index (NDVI) [25]. This approach is particularly successful in the Brazilian semi-arid regions due to the strong synchronicity between phenology and plant-water availability [3].

An alternative approach to monitor vegetation phenology is near-surface RS, which uses in-situ automated cameras (phenocams) [26]. This technique, in combination with EC measurements and remote sensing, has been applied in Brazilian SDTFs [4] to investigate 
the drivers that regulate phenological patterns and vegetation responses to seasonal and severe droughts.

Regarding water use, EC and RS can be used to estimate ET [25], a flux that encompasses processes other than transpiration, such as evaporation of soil water, canopyintercepted water, and other free water surfaces. However, RS generally provides discontinuous time series of ET (e.g., due to cloudy conditions) [27]. Moreover, none of these tools allow direct measurements of transpiration at the individual tree or species level. Hence, these techniques cannot explain species-specific strategies that are strongly dependent on individual structural, phenological, and physiological traits. For such, in-situ or near-surface methods make monitoring possible.

Continuous in-situ estimation of transpiration is possible with sap flow sensors. Among the methods used to estimate sap flow, thermal dissipation probes (TDP) have been widely used and improved throughout the years [28]. Information on transpiration is essential for studies related to plant water use, including those in SDTFs [29,30]. Sap flow measurement techniques can provide time series of diurnal and seasonal water fluxes to estimate plant water use. The TDP method, suggested by Granier [31,32], is widely applied to estimate tree transpiration because the sensor system is simple to construct, easy to install, and relatively inexpensive [33,34].

When analysing time series and patterns of water use, vapor pressure deficit (VPD) has been considered as the main environmental driver of plant transpiration under most conditions, representing the atmospheric demand Grossiord 2019 [35]. performed continuouslylogged sap flow monitoring experiments in humid tropical forests and observed that sap flow was highly dependent on VPD. However, for the less humid regions studied, very high VPD led to a reduction in transpiration as a result of the strong negative dependence of stomatal opening on VPD Grossiord et al. Similarly, Butz et al (2018) monitored sap flow of both deciduous and non-deciduous species and showed that evergreen species have a stronger relationship with seasonal VPD variation than deciduous ones, and a slightly higher dependence of sap flow on soil moisture than on VPD. Overall, these studies indicate that in more water-limited systems, species will be more dependent on soil water availability.

Here, we combine several datasets and approaches, as well as ground truth data, in order to test the efficiency of remote sensing data to monitor a significant physiological process such as water use. We aim to investigate the relationship between plant water use and phenology for Caatinga woody plant species at both the species and community level using different scales: moderate RS spatial resolution, high RS spatial resolution, and nearsurface cameras. In addition, we intend to evaluate the environmental drivers and factors that limit plant phenology (leaf flush and senescence) and transpiration. We hypothesize that: (1) phenology at the community level (represented by RS data) and at the species level (represented by near surface remote sensing data) are fully explained by soil water availability; (2) RS data for the Caatinga vegetation are strongly correlated to variations in water use strategies among species; (3) variations in the sap flow signal are fully explained by changes in water availability.

\section{Materials and Methods}

\subsection{Study Site}

The study site (Figure 1) is located in central-northern part of the Brazilian state of Pernambuco, in the municipality of Serra Talhada $\left(7^{\circ} 58^{\prime} 12^{\prime \prime} \mathrm{S}, 38^{\circ} 23^{\prime} 06^{\prime \prime} \mathrm{W}, 455 \mathrm{~m}\right.$ a.s.l.). The soils are predominantly Aridisols Argid and Entisols orthents [36]. The area has a relatively smooth relief and comprises various xerophilous vegetation types [37]. The local climate is Bsh (arid-steppe-hot arid) according to the Köppen system in a transition region to the Aw (winter dry season) [38-40], with a mean annual rainfall of $680 \mathrm{~mm} \mathrm{yr}^{-1}$ and a mean temperature of $23.8^{\circ} \mathrm{C}$ [40]. The experimental site includes a $50 \times 100 \mathrm{~m}$ monitoring plot (Figure 1) which is part of the Nordeste project plot network [41], and a $10 \mathrm{~m}$ tall eddy 
covariance (EC) flux tower (site ID BR-CST in AmeriFlux network; $7.9682^{\circ} \mathrm{S}, 38.3842^{\circ} \mathrm{E}$ ) located $200 \mathrm{~m}$ away from the monitoring plot.

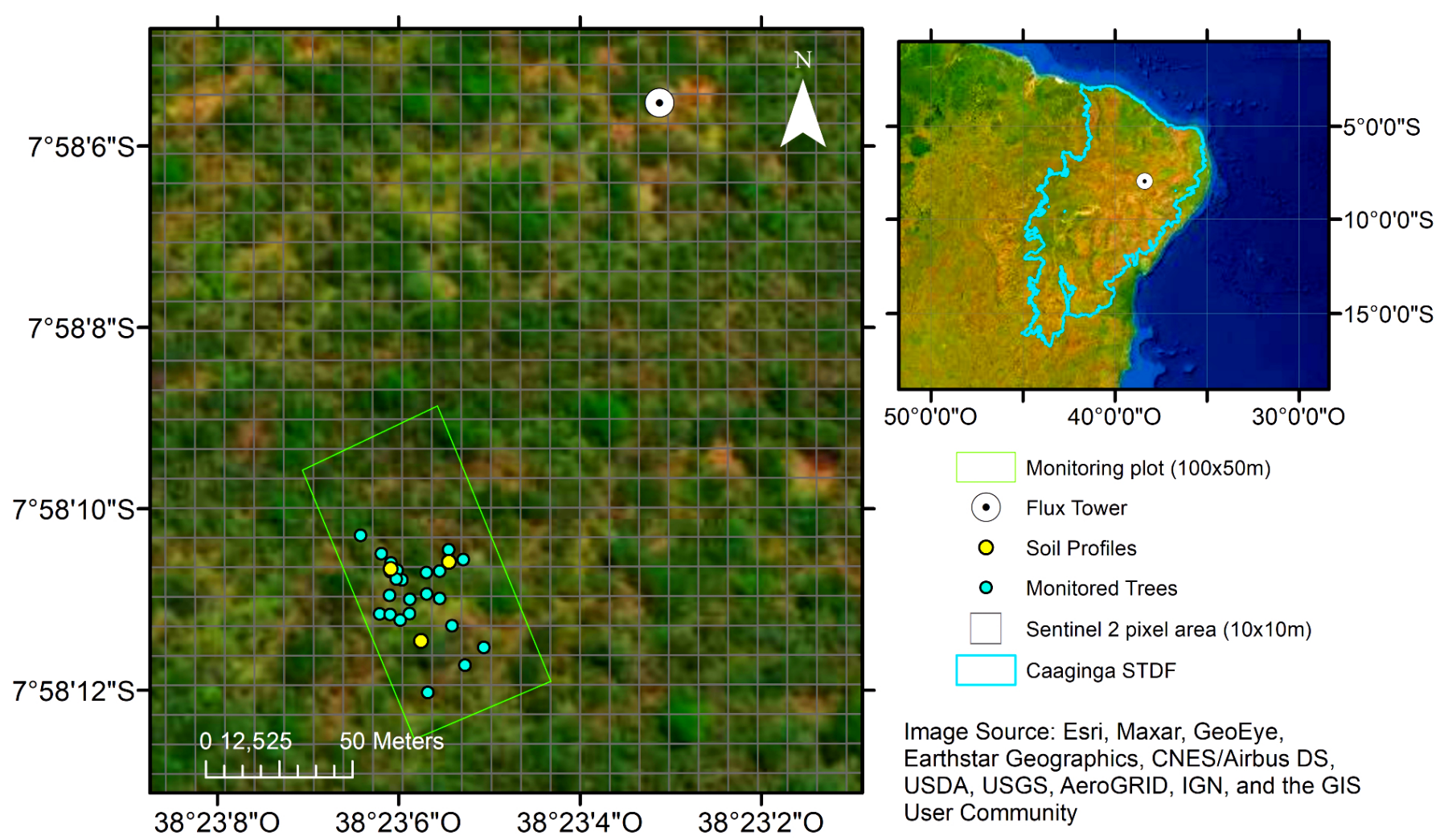

Figure 1. Study site: Map of the study area showing eddy covariance (EC) flux tower location (where the phenocam is installed), and the monitoring plot (where sap flow and soil moisture sensors were installed); location of the study site in the context of the Brazilian Caatinga. Spatial resolution: $15 \mathrm{~cm}$.

Our study was carried out from April 2018 to March 2019, during which the in-situ pluviometer registered a pronounced rainy season from December to April (total precipitation of $499 \mathrm{~mm}$ ), whereas the dry period lasted from May to November (total precipitation of $40 \mathrm{~mm}$ ). Regarding the total rainfall in April, which marked the beginning of our experiment, that month was considered the wet-to-dry transition period. These precipitation values and their timing are consistent with the normal climate found for this region [40]. Therefore, the results found in this work can be extended to other years with normal rainfall.

\subsection{Experimental Strategy}

The experimental design is shown in the flowchart (Figure 2). In terms of ground data, the experimental strategy consists in: (i) measuring the sap flux density $\left(\mathrm{F}_{d}\right)$ on individual tree species found within the monitoring plot and normalizing it among the sampled species $\left(\mathrm{F}_{d n}\right)$; (ii) upscaling the normalized flux density $\left(\mathrm{F}_{d n}\right)$ to the level of the plot (or community; $\mathrm{F}_{d n c}$ ); (iii) comparing the $\mathrm{F}_{d n}$ with the soil water availability. The purpose of these measurements was to evaluate the main drivers affecting the physiological response of Caatinga trees (i.e., the plant-water availability and VPD). To test the relationship between plant physiology patterns (sap flow density) and leaf phenology, we used VIs obtained from different sources. Besides being used as a proxy of leaf phenology, VIs from different sources were also evaluated in terms of their ability to represent certain physiological process, such as intra-annual variability of sap flow. 


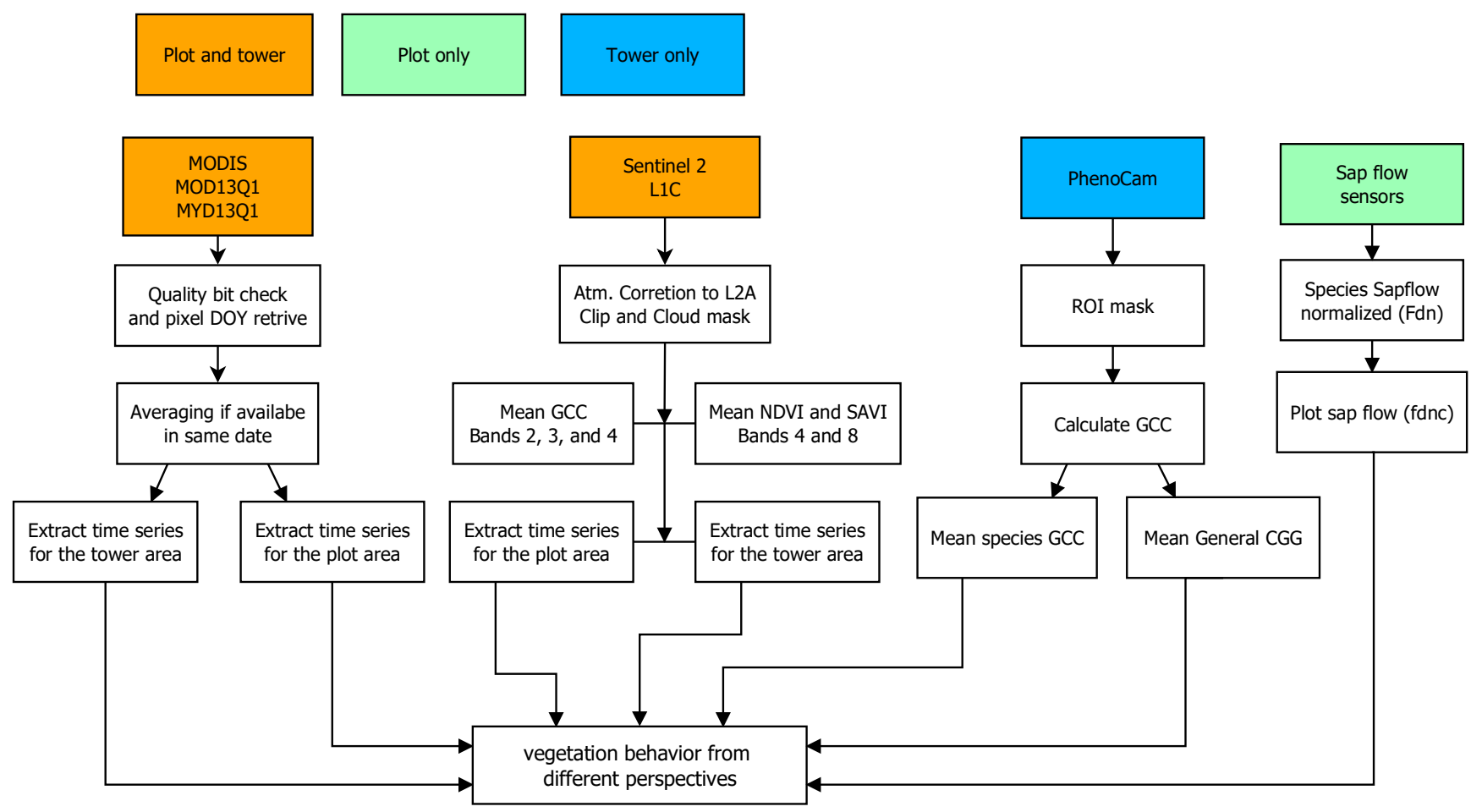

Figure 2. Flowchart of the experimental design.

\subsubsection{Plant Species}

A total of 24 species were found in the plot, of which 11 showed a dominance over 1.0: Anadenanthera colubrina (Vell.) Brenan, Aspidosperma pyrifolium Mart. \& Zucc, Astronium urundeuva Engl., Cenostigma nordestinum Gagnon \& G.P.Lewis, Cereus jamacaru DC., Commiphora leptophloeos (Mart.) J.B. Gillett, Croton echioideus Baill., Erythroxylum pungens O.E.Schulz, Mimosa acutistipula Benth. Piptadenia flava Benth. and Senegalia polyphylla (DC.) Britton \& Rose.

We selected five species to monitor sap flow density, which accounted for $80 \%$ of the total dominance: C. leptophloeos; A. colubrina; S. polyphylla and; A. pyrifolium; C. nordestinum. All selected species are deciduous and were selected based on their abundance registered in the inventory of the monitoring plot and the Nordeste project plot network [41], and based on their relative abundance, as indicated in Table 1.

Table 1. Tree species monitored, wood density $\left(W_{d}, \mathrm{~g} \cdot \mathrm{cm}^{-3}\right)$, mean diameter at breast height (DBH) mean species height (H.), dominance in the plot (D.), estimated sum of the sapwood area per species per species, percentage of the sapwood area in relation to the total sapwood area in the plot.

\begin{tabular}{ccccccc}
\hline Species & $\boldsymbol{W}_{\boldsymbol{d}}$ & DBH $(\mathbf{c m})$ & H. $(\mathbf{m})$ & D. $(\mathbf{\%})$ & Sap. Area $\left(\mathbf{c m}^{2}\right)$ & \% of Total Sap. \\
\hline Anadenanthera colubrina & 0.59 & 13.4 & 7.2 & 4 & 175 & 6.2 \\
Aspidosperma pyrifolium & 0.54 & 8.1 & 4.9 & 30 & 772 & 27.3 \\
Cenostigma nordestinum & 0.66 & 13.8 & 5.4 & 30 & 1751 & 78 \\
Commiphora leptophloeos & 0.28 & 20.0 & 5.2 & 1 & 49 & 2.8 \\
Senegalia polyphylla & -- & 15 & 7.7 & 5.4 & 2824 & 1.7 \\
Total & -- & 80 & -- & -- & 100 \\
\hline
\end{tabular}


All plant specimens were collected and identified by botanists at the Herbarium of the State University of Feira de Santana (HUEFS) Bahia, Brazil. The inventory included all plant individuals with a diameter at breast height $(\mathrm{DBH})$ over $5 \mathrm{~cm}$; the average height of trees in the plot was $5.2 \mathrm{~m}$. Abundance of each species was determined by establishing the frequency of individuals of a given species within the monitoring plot.

We estimated sapwood depth using the linear regression given by $0.377 * \mathrm{DBH}-1.075$, $\mathrm{R}^{2}$ of 0.67 ( $p<0.05$ for both coefficients). Additionally, we estimated the total sapwood area for all individuals of a given species, calculated the sapwood area of each species, and estimated the percentage of the total active xylem area for each species Table 1.

\subsubsection{Ground Measurements}

Sap flux density $\left(\mathrm{F}_{d}, \mathrm{~g} \mathrm{~m}^{-2} \mathrm{~min}^{-1}\right)$ for the selected individuals was measured using Granier's TDP method (see Supplementary Materials, Section S1C). The sap flux density at the individual level $\left(\mathrm{F}_{d}\right)$ was first normalized, yielding $\mathrm{F}_{d n}$, and then scaled-up to the community level, $\mathrm{F}_{d n c}$, considering the relative sapwood area of each species (Table 1). At the community level, $\mathrm{F}_{d n c}$ was calculated as the weighted average considering the relative contribution of the sapwood area for each species. The environmental drivers and plant traits used in the sap flow and phenology analysis are described in Table 2. The environmental drivers and plant traits used in the sap flow and phenology analysis were: vapour-pressure deficit (VPD) and plant water availability-expressed in terms of soil water content $\left(\mathrm{S}_{w}\right)$ and relative soil water saturation $\left(S_{e, p r o f} ;\right.$ Table 2$) . \mathrm{S}_{w}$ is the amount of water for the total soil profile of $77.5 \mathrm{~cm}$. $S_{e, p r o f}$ is a fraction between; dependent on the actual profile soil moisture, $\theta_{\text {prof }}$, and the difference between the saturated profile moisture content, $\theta_{s, p r o f}$, and residual profile moisture content, $\theta_{r, p r o f}$ (see Supplementary Materials Equation (S2)). For more details, see Supplementary Materials, as indicated in Table 2.

Table 2. Summary of measured or derived environmental variables: category of the variable; name; description; units; section number. See the Supplementary Material for more details.

\begin{tabular}{|c|c|c|c|c|}
\hline Category & Variable & Description & Unit & SM s nr. \\
\hline \multirow{4}{*}{ Atmospheric driving } & $R_{n}$ & Net Radiation & $\mathrm{W} \mathrm{m}^{-2}$ & 1.A \\
\hline & $T_{\text {air }}$ & Air temperature & ${ }^{\circ} \mathrm{C}$ & 1.A \\
\hline & VPD & Vapour-pressure deficit & $\mathrm{hPa}$ & 1.A \\
\hline & $\mathrm{P}$ & Rainfall & $\mathrm{mm}$ & 1.A \\
\hline \multirow{2}{*}{ Soil moisture status } & $S_{e, p r o f}$ & Relative saturation & - & 1.B \\
\hline & $W_{s}$ & Soil Water Storage & $\mathrm{mm}$ & $1 . \mathrm{B}$ \\
\hline \multirow{3}{*}{$\begin{array}{l}\text { Transpiration and } \\
\text { evapotranspiration }\end{array}$} & $\mathrm{F}_{d n}$ & Sap flow density normalized & - & 1.C \\
\hline & $\mathrm{F}_{d n c}$ & Community sap flow normalized & - & 1.C \\
\hline & $E T$ & EC evapotranspiration & mm month ${ }^{-1}$ & 1.A \\
\hline \multirow{3}{*}{ Plant trait } & $W_{d}$ & Wood density & $\mathrm{g} \cdot \mathrm{cm}^{-3}$ & * \\
\hline & Dominance & Relative frequency abundance & $\%$ & 1.C \\
\hline & Sap. area & Sum of estimated species sapwood area & $\mathrm{cm}^{2}$ & 1.C \\
\hline
\end{tabular}

\subsubsection{Remote Sensing Data}

Information on land surface phenology and vegetation indexes (VIs) was obtained from remote sensing (RS) sensors which operate at different spatial and temporal scales: remote sensors MODIS/Terra + Aqua (250 m products MYD13Q1 and MOD13Q1) and MSI/Sentinel-2A + B (10 m), and near-surface remotely sensed data, obtained by one phenocam (Mobotix AG-Germany) installed at the top of the EC flux tower (see Supplementary Materials, Section S1A). The VIs derived from these RS products are NDVI (MODIS and Sentinel-2A), GCC (Sentinel-2A and phenocam) and SAVI (Sentinel-2A), as presented in Table 3.

Because of the rapid dynamics of the Caatinga vegetation, which responds to rain and soil water content within a few days, a short revisit time satellite was necessary. 
The Sentinel-2 satellite was chosen because of its spatial resolution $(10 \mathrm{~m})$ and mainly because of its revisit time (3-10 days). The MODIS sensor was chosen for comparison purposes. Despite its moderate spatial resolution $(250 \mathrm{~m})$ considering the dimensions of our plot, the high revisit frequency and well known product quality provides a simple and effective way to compare the performance of the Sentinel-2 index. Since our objective is to analyze forest change over time, comparing the variables with a product resulting from a very low revisit time is essential (Terra and Aqua satellites cross every day, morning and afternoon, providing temporal VI products with much less cloud probability). The phenocam provided the field truth for the region and also enabled us to evaluate the phenology of each species separately.

Table 3. Remote Sensing data: Variable; Sensor/Satellite, spatial resolution; temporal resolution; respective section. Please see the Supplementary Materials for more details.

\begin{tabular}{ccccc}
\hline Variable & Sensor/Satellite & Spatial Resolution & Temporal Resolution & Section nr. \\
\hline $\mathrm{NDVI}_{\text {modis }}$ & MODIS/TERRA + AQUA & $250 \mathrm{~m}$ & 8 days * & $1 . \mathrm{D}$ \\
$\mathrm{NDVI}_{S 2}$ & MSI/Sentinel 2A + 2B & $10 \mathrm{~m}$ & $3-10$ days & $1 . \mathrm{D}$ \\
$\mathrm{GCC}_{S 2}$ & MSI/Sentinel 2A + 2B & $10 \mathrm{~m}$ & $3-10$ days & $1 . D$ \\
$\mathrm{GCC}_{n s}$ & Near surface camera/NA & daily & $1 . D$ \\
$\mathrm{SAVI}_{S 2}$ & MSI/Sentinel 2A + 2B & $10 \mathrm{~m}$ & 3-10 days & 1.D \\
\hline
\end{tabular}

* pixel composition from daily image acquisitions; ${ }^{* *}$ camera spatial resolution depends on the distance from camera's nadir.

The proportion of canopy coverage in relation to soil exposure is also seen by Sentinel2 and MODIS. The coverage was considered spatially homogeneous since no significant differences $(p>0.5)$ were found between the temporal behavior of the sentinel individual pixels and individual species. This was due to the proximity of trees from different species, sometimes less than two meters, but also due to the spatial autocorrelation of the pixels. Each pixel influences its neighborhood [42], reducing the effective pixel resolution. It is worth mentioning that the spatial miss-registration in the Sentinel-2 images series vary by around $12 \mathrm{~m}$ (more than one pixel) but can be greater than 3 pixels according to [43]. For all these reasons, it was not possible to analyze the temporal behavior of Sentinel-2 pixels individually. Thus, a temporal profile was extracted considering the pixel mean of the monitoring plot area.

Regarding the phenocam images, the regions of interest (ROIs) were selected at the species and at the community level. At the species level, we selected pixels corresponding to the tree crowns of the four species found within the phenocam's field of view (Figure 3). S. polyphylla, which represents only $1.7 \%$ of the total sapwood area, was not present within the camera's field of view. We then extracted the GCC for each ROI and calculated the mean GCC for each species $\left(\mathrm{GCC}_{n s, e}\right.$. At the community level, we selected the ROI pixels corresponding to the entire vegetated area in the image, excluding bare soil and the tower (Figure 4). The community ROI includes trees, shrubs, and eventual forbs if present. The GCC was extracted from the community's ROI. Conservatively, the same ROI was used for the community during the entire study period, including the dry and rainy seasons. Figure 4 shows the contrast between the seasons: the fully developed tree crowns in the rainy season and the leafless crowns during the dry season.

\subsection{Data Analysis}

In order to establish relationships between plant water use and environmental drivers, we compared the temporal variability of $\mathrm{F}_{d n c}$ with the environmental data obtained from the micrometeorological flux tower (i.e., VPD, $\mathrm{R}_{n}$ and $\mathrm{T}_{\text {air }}$ ) and with the relative saturation, $S_{e, p r o f}$. To identify the relationship at the community level, we used the same approach to compare $\mathrm{F}_{d n c}$ with NDVI (MODIS and Sentinel-2) and GCC $_{S 2}$.

The VIs (GCC, SAVI, and NDVI) used to compare with the results obtained from the phenocams $\left(\mathrm{GCC}_{n s}\right)$ were calculated for the tower region; we assumed that the tower region consisted of a circle around the flux tower with a radius of $50 \mathrm{~m}$, which is compatible 
with the camera field of view. The VIs (Table 3$)$ used to compare with the sap flow ( $\mathrm{F}_{d n}$ and $\mathrm{F}_{d n c}$ ) data and with $S_{e, p r o f}$ were calculated using the pixels that covered the monitoring plot area (Figure 1).

To compare the VIs obtained from different scales, we used the transition dates of start (SOS) and end (EOS) of the growing season. The length of the growing season and associated phenological transitions, SOS and EOS [21], were calculated from the phenocam GCC and the RS vegetation indices GCC, SAVI, and NDVI based on Alberton et al. 2019.

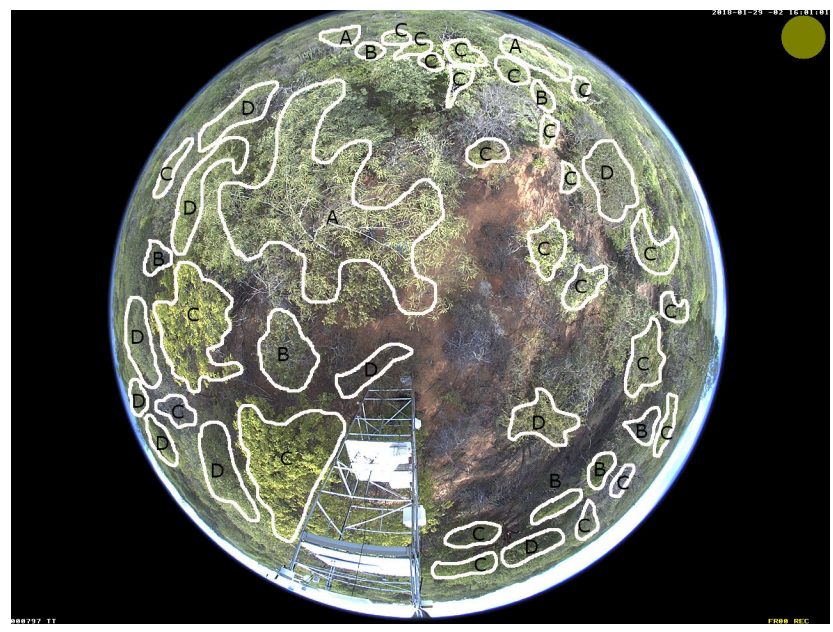

Figure 3. Example of a hemispherical image used for the proximal remote sensing phenological analyses at the study site, PE-Brazil. The areas selected in white represent tree crowns of individuals from four species: A, Anadenanthera colubrina; B, Aspidosperma pyrifolium; C, Cenostigma nordestinum and D, Commiphora leptophloeos.
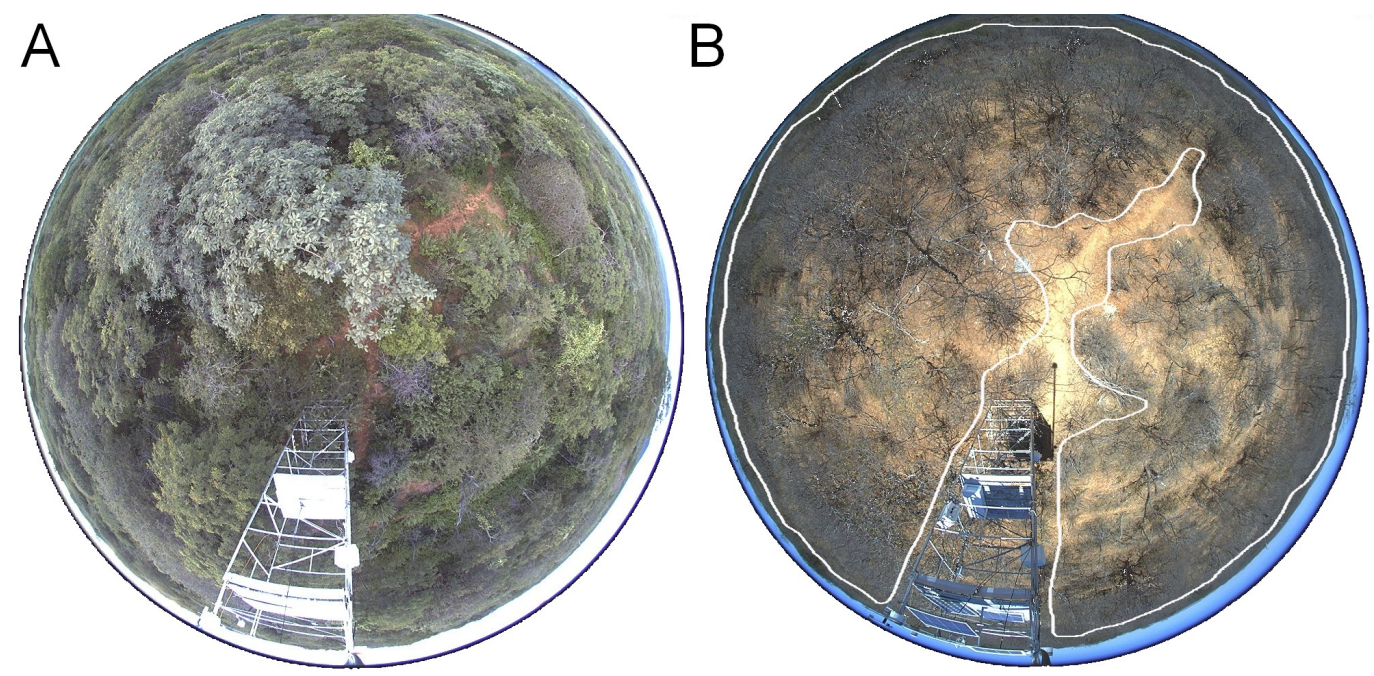

Figure 4. Hemispherical image used for the proximal remote sensing phenological analyses at the study site, PE-Brazil; (A) In the rainy season day of year (DOY) 107, 2018. (B) In the dry season DOY 256,2018 ; the area selected in white represents the entire vegetation sampled as the region of interest (ROI) of the community for the extraction of phenological indices.

This method uses the confidence intervals of curve derivatives to identify changes in phenology [4]. First, we fitted a generalized additive model (GAM) using the species and community GCC as the response variable fitted by the sequence of consecutive days (time) of the phenological observations, which was used as an independent smoother variable to produce the phenological curves. We then calculated which regions of the curve had derivatives and detected when the derivatives were increasing (to determine SOS) 
or decreasing (to determine EOS) [4]. We considered SOS as the first day detected on the derivative at the left side of the GCC curve and EOS as the last day of the derivative at the right side of the curve. The transition dates calculated from the phenocam GCC were verified by visual inspection of the digital images and adjusted when necessary (for more details see Supplementary Materials Section S1D).

In addition, to evaluate whether variations in wood density could explain differences in water use and transition dates, we assessed species' wood density $\left(W_{d}, \mathrm{~g} \cdot \mathrm{cm}^{-3}\right)$ and the difference between $\mathrm{F}_{d n}$ time series and near-surface GCC for each species.

Finally, the $\mathrm{F}_{d n c}$ data were compared with the VI that showed the greatest correlation with $\mathrm{F}_{d n c}$. Thus, we compared NDVI indices $\left(\mathrm{NDVI}_{\text {modis }}\right.$ and $\left.\mathrm{NDVI}_{S 2}\right)$ with $S_{e, p r o f}$ using scatter plots in order to explicitly assess the dependence between variables across their data range.

\section{Results}

\subsection{Hydroclimatological Drivers of Sap Flux Density}

Figure 5 a shows that the net radiation, $\mathrm{R}_{n}$, was relatively low between April and August. This is part of the dry and cooler period where shortwave and longwave incoming radiation are lower than during the wet period, while albedo and longwave outgoing radiation are relatively more frequent, as previously observed in the Caatinga [22,44]. $R_{n}$ remained approximately constant after September. The ET, shown in Figure 5b, varies between 0 and $125 \mathrm{~mm} \mathrm{month}^{-1}$, and the lowest values were found between August and November, when rainfall, $(\mathrm{P})$ was negligible (see Figure 5a). Despite the low $\mathrm{P}$ in May and June, ET is still considerable because of the total water stored $\left(\mathrm{S}_{w}\right)$ in the soil profile (see Figure 5c), which allows transpiration to continue. It is worth noting that for leaves that are well-coupled to the atmosphere (i.e., with open stomata), the transpiration at the leaf level can be approximated by the product of the leaf-to-air VPD and the stomatal conductance according to Fick's law of diffusion [45]. However, in this region, our results show that intra-annual ET was inversely related to VPD $(p<0.05)$ (Figure 5b), most likely because, despite the higher VPD, plant species are mostly leafless from September to November.

The ET is in phase with $S_{w}$. The latter varied from a maximum of $184 \mathrm{~mm}$ at the beginning of April to a minimum of $74 \mathrm{~mm}$ at the end of November. However, after September $S_{w}$ remained fairly constant (approximately $75 \mathrm{~mm}$ ) until November when the rains started (Figure 5c). The highest air temperatures, $\mathrm{T}_{\text {air }}$, coincided with the lowest values of ET, underlining the harsh climatic conditions during the dry season. $\mathrm{T}_{\text {air }}$ varied between $24^{\circ} \mathrm{C}$ in July and $28.5^{\circ} \mathrm{C}$ in November.

The community-level sap flow, $\mathrm{F}_{d n c}$ (Figure $5 \mathrm{~d}$ ), is in phase with $\mathrm{S}_{w}$ and ET. However, ET increased rapidly during the first rainy month, while $\mathrm{F}_{d n c}$ increased gradually, suggesting that a large part of the ET recorded during the first rainy month may be due to the evaporation of intercepted water and/or to soil water evaporation. Furthermore, the $\mathrm{F}_{d n c}$ varies in synchrony with the vegetation indices $\mathrm{GCC}_{S 2}, \mathrm{NDVI}_{S 2}$, and $\mathrm{NDVI}_{\text {modis }}$ (Supplementary Materials, Figure S2). 
(a)

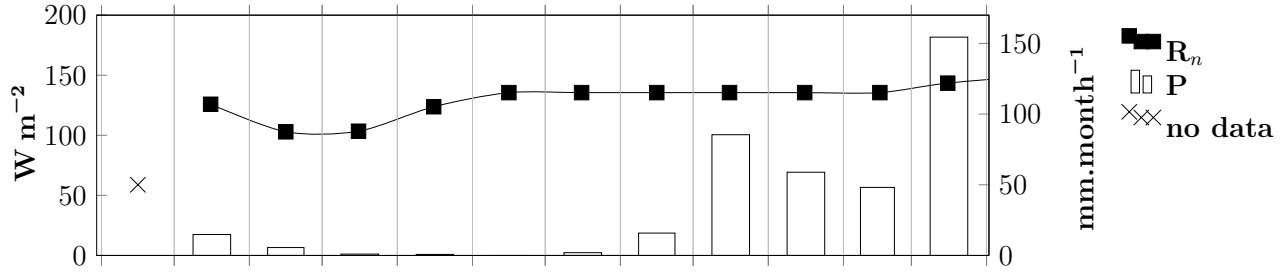

(b)
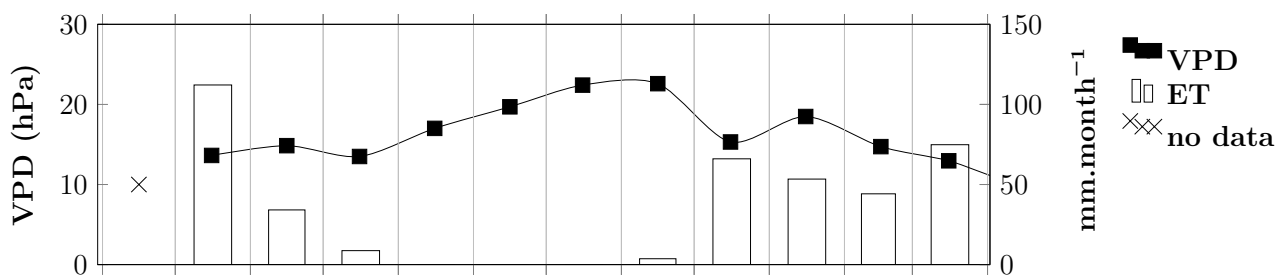

(c)
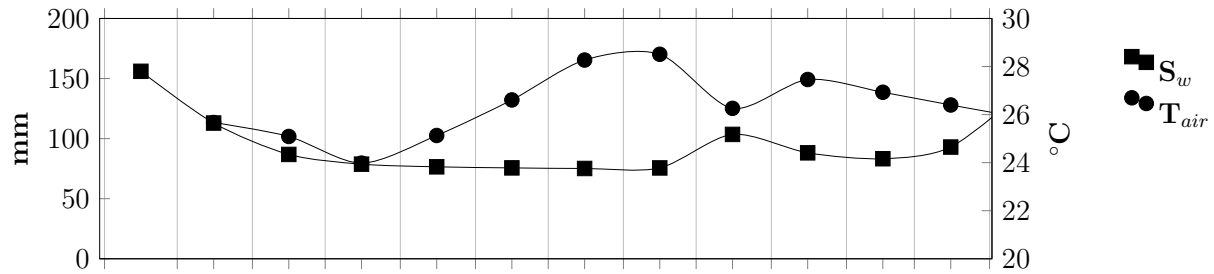

(d)

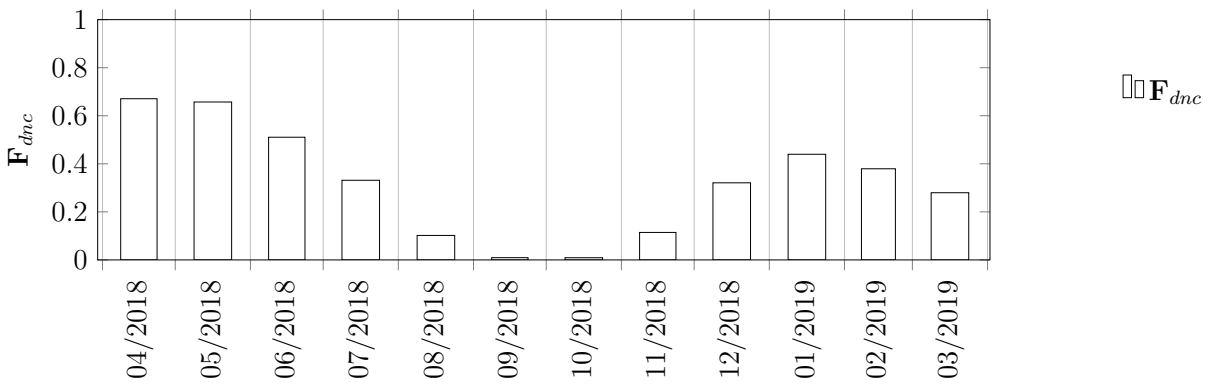

Figure 5. Climate variables, soil water availability, and community-level sap flow: (a) Net Radiation $\left(\mathrm{R}_{n}, \mathrm{~W} \mathrm{~m}^{-2}\right.$ ) and rainfall (P, mm month $\left.{ }^{-1}\right)$; (b) vapour pressure deficit (VPD, hPa) and EC evapotranspiration $\left(\mathrm{ET}, \mathrm{mm}\right.$ month $\left.^{-1}\right)$; (c) soil water storage $\left(\mathrm{S}_{w}, \mathrm{~mm}\right)$ and monthly mean air temperature $\left(\mathrm{T}_{\text {air }} ;{ }^{\circ} \mathrm{C}\right) ;(\mathrm{d})$ Normalized sap flow for the plot community $\left(\mathrm{F}_{d n c}\right.$, dimensionless).

\subsection{Transpiration, Soil Water Condition, and Remote Sensing Data}

The normalized sap flux density at the species level, $\mathrm{F}_{d n}$, was strongly affected by soil conditions when $S_{e, p r o f}$ was below 0.25 (Figure 6), indicating the high dependency of transpiration on stored water and demonstrating the threshold when plant water stress starts to limit transpiration. GCC and $\mathrm{F}_{d n}$ increased rapidly after the first rain, even with low water availability $\left(S_{e, p r o f}\right.$ around 0.18$)$, for all species except $A$. pyrifolium. After December 2019 , the sap flow signal varied reasonably, but still followed the evolution of $S_{e, p r o f}$. This is due in part to climate variations, but also to the fact that a number of sensors failed during this period. Thus, the average $\mathrm{F}_{d n}$ for certain months was not based on all four sap flow sensors. All individuals from the studied species had a fully developed canopy at the beginning of the sap flow measurements. Therefore, our study period included two transition dates, the EOS of the ongoing growing season (2017-2018) and the SOS of the second growing season (2018-2019). Moreover, leaf fall still occurred after the EOS in the rainy season in 2018, and a SOS with new leaf flushing was detected at the beginning of the next rainy season in December of 2019. All species showed a negative correlation to daily VPD since all are deciduous and lost their leaves, halting transpiration precisely in the periods when VPD was highest.

Despite their approximate correspondence (Figure 6), as both variables exhibit a strong seasonality, the correlation between $\mathrm{F}_{d n}$ and GCC obtained from the proximal RS was poor (see Table 4, last column; the highest correlation (0.51) was found for A. colubrina and 
C. nordestinum, species with high wood density). In fact, $\mathrm{F}_{d n}$ and $\mathrm{F}_{d n c}$ have a stronger relationship with all RS indices, especially with NDVI (Table 4). NDVI modis data better explained the variation in $\mathrm{F}_{d n c}$ than $\mathrm{NDVI}_{S 2}$, Table 4 shows a Pearson correlation coefficient of $0.92(p<0.01)$ versus a value of $0.88(p<0.01)$.

(a)

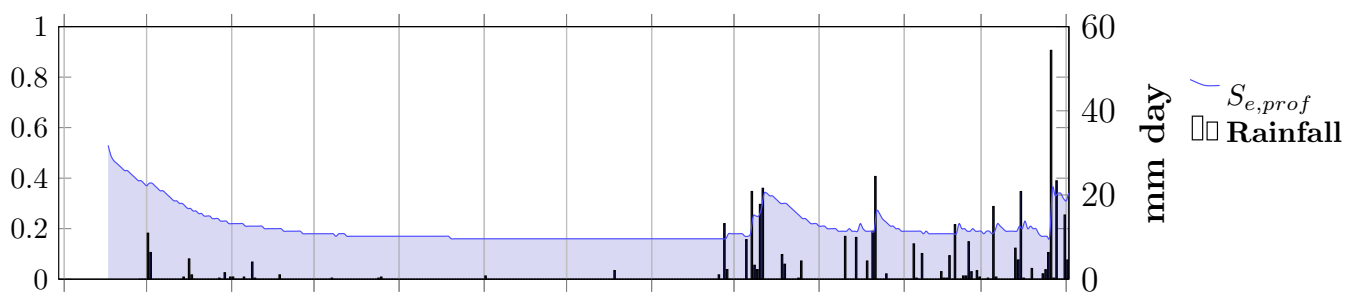

(b)

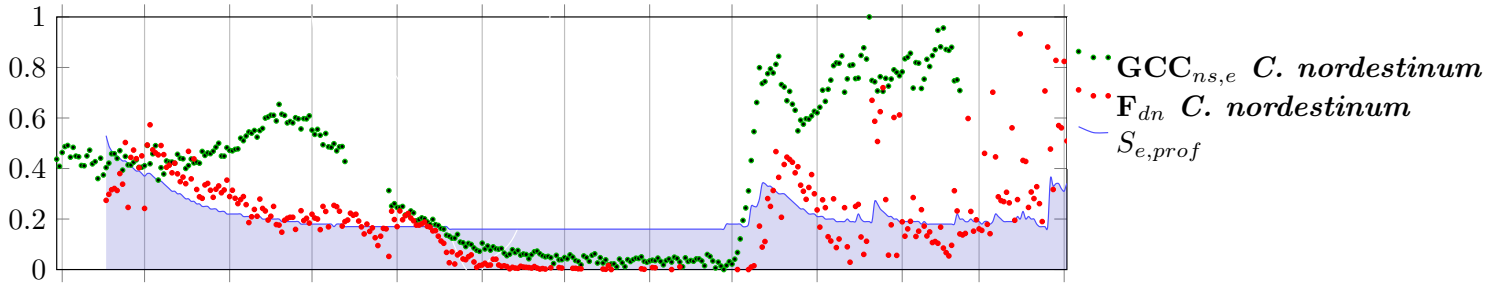

(c)

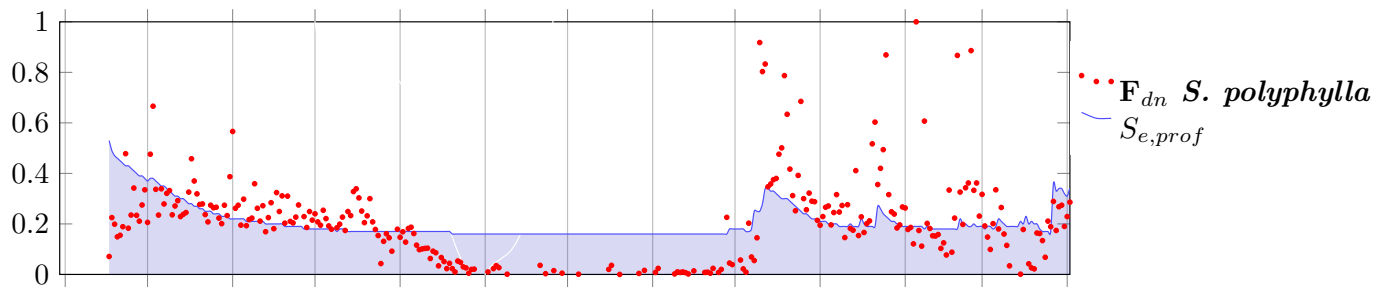

(d)

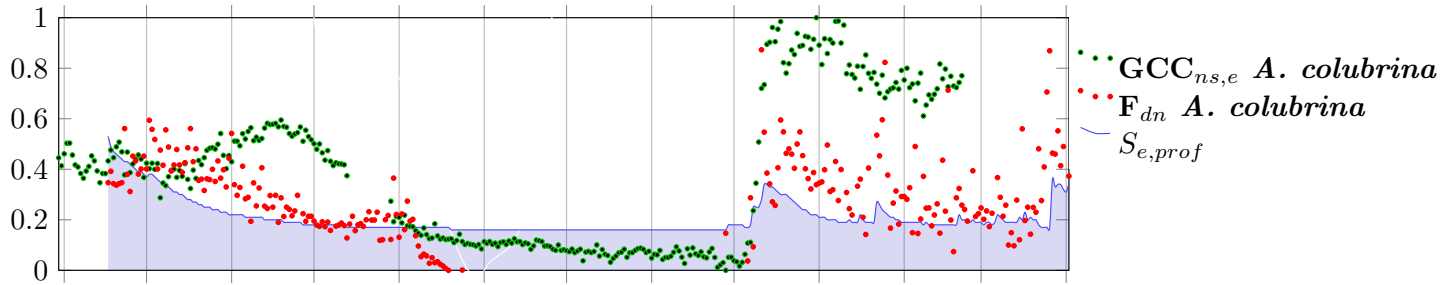

(e)

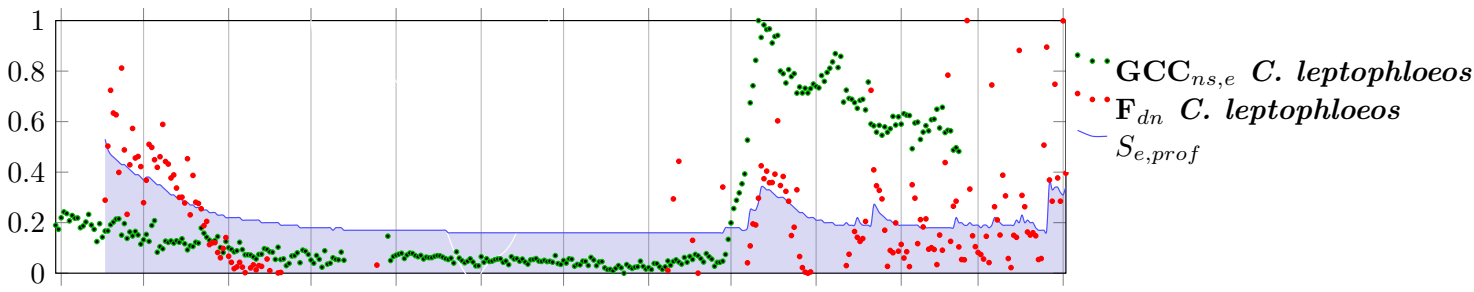

(f)

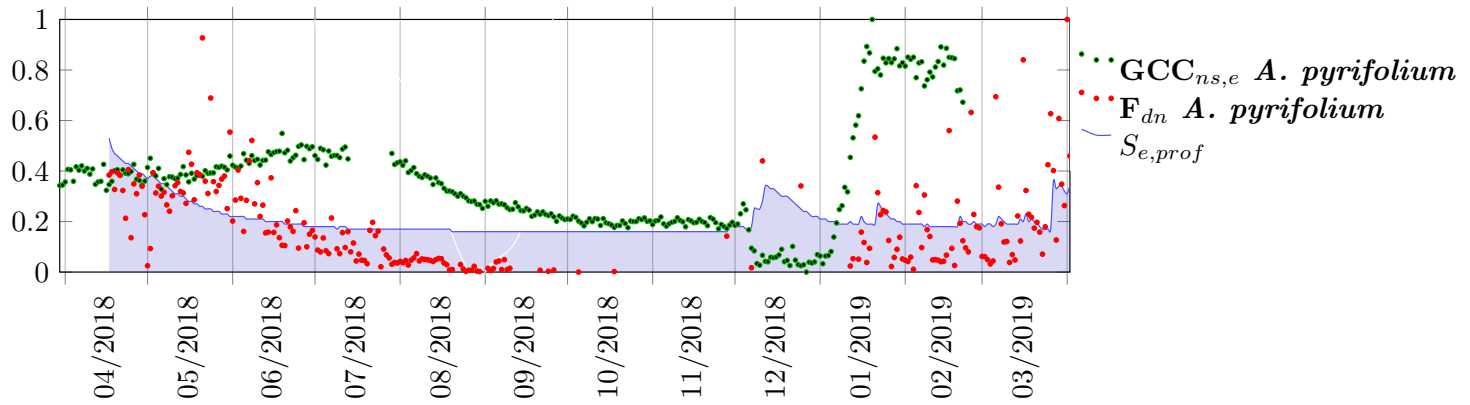

Figure 6. (a) Rainfall $\left(\mathrm{mm} \mathrm{day}^{-1}\right)$ and soil water profile relative saturation ( $S_{e, p r o f}$, dimensionless); and normalized near surface species GCC $\left(\mathrm{GCC}_{n s, e}\right.$, dimensionless), and species averaged sap flow density ( $\mathrm{F}_{d n}$, dimensionless), together with $S_{e, p r o f}$ for (b) C. nordestinum and $S_{e, p r o f} ;(\mathbf{c})$ S. polyphylla; (d) A. colubrina; (e) C. leptophloeos; (f) A. pyrifolium. 
Table 4. Pearson correlation coefficient between $\mathrm{F}_{d n}$ and $\mathrm{NDVI}_{\text {modis }}, \mathrm{NDVI}_{S 2}, \mathrm{GCC}_{S 2}, \mathrm{SAVI}_{S 2}$ and $\mathrm{GCC}_{n s}$, respectively.

\begin{tabular}{|c|c|c|c|c|c|}
\hline $\mathrm{F}_{d n}$ & $\mathrm{NDVI}_{\text {modis }}$ & $\mathrm{NDVI}_{S 2}$ & $\mathrm{GCC}_{S 2}$ & $\mathrm{SAVI}_{S 2}$ & $\mathrm{GCC}_{n s}$ \\
\hline A. colubrina & 0.83 * & 0.80 * & 0.71 * & 0.74 * & 0.36 * \\
\hline A. pyrifolium & $0.76^{*}$ & 0.78 * & 0.67 * & 0.79 * & -0.14 \\
\hline C. leptophloeos & 0.31 & 0.49 & $0.55^{*}$ & $0.56^{*}$ & 0.06 \\
\hline C. nordestinum & 0.85 * & 0.71 * & $0.68 *$ & 0.63 * & 0.51 * \\
\hline S. polyphylla & 0.82 * & 0.73 * & $0.71^{*}$ & 0.62 * & - \\
\hline $\mathrm{F}_{d n c}$ & 0.92 * & 0.88 * & 0.84 * & 0.81 * & \\
\hline
\end{tabular}

The transition dates (in format DD/MM/YY) calculated for each species were the following: A. pyrifolium: $\mathrm{EOS}=10 / 08 / 18, \mathrm{SOS}=10 / 01 / 19 ;$ C. nordestinum: $\mathrm{EOS}=05 / 08 / 18$, $\mathrm{SOS}=08 / 12 / 18 ;$ C. leptophloeos: $\mathrm{EOS}=12 / 06 / 18, \mathrm{SOS}=11 / 12 / 18 ;$ A. colubrina $: \mathrm{EOS}=$ $03 / 08 / 18, \mathrm{SOS}=07 / 12 / 18$. Based on visual inspections of the images, we found that during the period between EOS and SOS, all individuals of the four species were leafless. The development dates for the tower region estimated by the sensors (Sentinel-2 and MODIS) can be seen in Table 5. We found that NDVI $_{\text {modis }}$ was the index with the highest correlation to species' water use, and its transition dates were the most similar to the $\mathrm{GCC}_{n s}$ results (Table 5).

Table 5. VI Transition dates (day of year/year) and bias in relation to near-surface GCC.

\begin{tabular}{cccccc}
\hline Transition Dates & GCC $_{\boldsymbol{n} \boldsymbol{s}}$ & GCC $_{\boldsymbol{S 2}}$ & NDVI $_{\boldsymbol{S 2}}$ & SAVI $_{\boldsymbol{S 2}}$ & NDVI $_{\text {modis }}$ \\
\hline EOS & $238 / 18$ & $220 / 18(-18)$ & $196 / 18(-42)$ & $191 / 18(-47)$ & $229 / 18(-9)$ \\
SOS & $339 / 18$ & $306 / 18(-33)$ & $305 / 18(-34)$ & $321 / 18(-18)$ & $309 / 18(-20)$ \\
\hline
\end{tabular}

Both the seasonal evolution of transpiration and the phenological response of the vegetation show an asymptotic limit in relation to $S_{e, p r o f}$ (Figure 7a,b), most likely because we are using $\theta_{s, \text { prof }}$ and $\theta_{r, p r o f}$ to normalise the data (please see the Supplementary Materials for an explanation of these parameters and of $\theta_{p w p}$ and $\theta_{f c}$ used below). During a considerable part of the year, the moisture content of the soil layers that contain most of the roots are below wilting point $\left(\theta_{p w p}\right)$, yet above the residual moisture content $\left(\theta_{f_{c}}\right)$. Additionally, not all of the water stored in the soil pores is used for transpiration, as part of it is stored below the root zone or lost to soil evaporation.
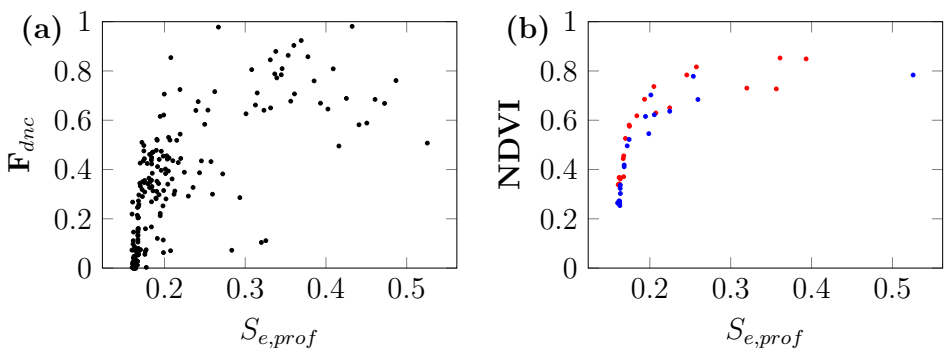

$\cdot \mathrm{NDVI}_{\text {modis }}$
. NDVI $_{S 2}$
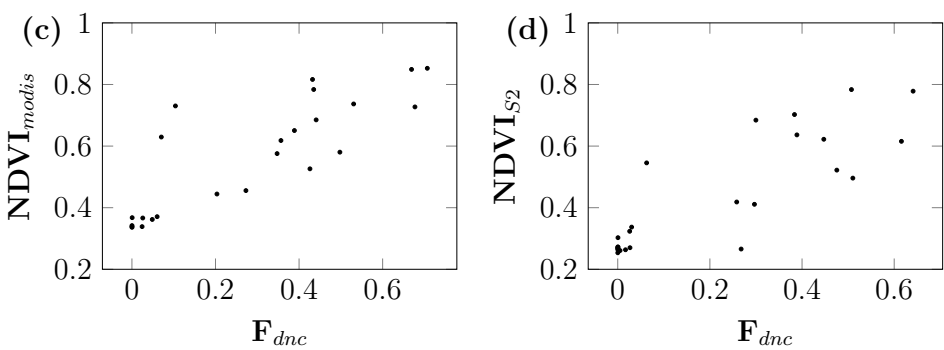

Figure 7. Scatter plots of (a) community level normalized sap flow $\left(\mathrm{F}_{d n c}\right)$ versus $S_{\text {prof }}$ (dimensionless), (b) $\mathrm{NDVI}_{\text {modis }}$ and $\mathrm{NDVI}_{S 2}$ versus $S_{\text {prof }},(\mathbf{c}) \mathrm{NDVI}_{\text {modis }}$ versus $\mathrm{F}_{d n c}$ (d) $\mathrm{NDVI}_{S 2}$ versus $\mathrm{F}_{d n c}$. 


\section{Discussion}

This study explored the sensitivity of remotely sensed indices to measure water use in the Caatinga. Our findings indicate that (i) the water use is highly dependent on soil moisture conditions; (ii) differences in wood characteristics seem to directly affect differences in when species sap flow ceases; (iii) with increasing resolution, from satellites with low resolutions to cameras that allow monitoring of individual tree species, new sources of uncertainties, previously masked by low spatial resolution, reduce correlations between RS indices and individual and community measurements of water use. Notwithstanding, the high resolution of the cameras has the benefit of allowing isolated events, such as the SOS and EOS, to be detected for different species.

It is remarkable how strongly $\mathrm{F}_{d n c}$ is related to $S_{e, p r o f}$, especially when considering daily values (Figure 6), which shows relative saturation together with rainfall, as well as greenness and sap flow per species. The strong seasonality, reflected in the highly variable sap flow values observed for all monitored Caatinga plant species, is evident and in agreement with previous studies [3,4,46]. Seasonality is particularly evident with regards to the timing of leaf shedding (EOS) and the drop in soil water storage $\left(\mathrm{S}_{w}\right)$ (Figure 5d). Moreover, the fact that seasonally varying values of $\mathrm{F}_{d n c}$ are only very weakly and negatively related to changes in VPD corroborates the idea that this vegetation is relatively independent of the atmospheric demand when considering intra-annual variation. This is not the case for the diurnal variation of sap flow (data not shown), which remains dependent on VPD as shown by Butz et al. (2018). These findings most likely reflect the fact that we considered a single value of $F_{d n c}$ and VPD for each day, thus the diurnal dependence (where sap flow increases as VPD increases) between these variables was not considered. The same effect occurs between the intra-annual variation of $\mathrm{R}_{n}$ and $\mathrm{F}_{d n}$ (Figure 5).

The inverse relationship between VPD and ET is also partially caused by the fact that, during the dry season, all trees shed their leaves and water uptake reduces to near-zero, despite the increase in VPD. Furthermore, during leaf-on periods with low atmospheric humidity, it is the strong negative dependence of stomatal opening on VPD that counteracts the concurrent increase in driving force, as mentioned in the introduction. Although the VPD values tend to be lower during the rainy season, thereby reducing potential transpiration, ET is high due to an increased water availability and related presence of leaves. Moreover, there is a strong relationship between VPD and $\mathrm{T}_{\text {air }}$ (Figure 5c), given the temperature depends on the saturated vapour pressure as calculated by Teten's formula [47]; around $57 \%$ of the VPD variation is caused by the variation in $\mathrm{T}_{\text {air }}$.

$\mathrm{F}_{d n c}$ appears to be independent of $S_{e, p r o f}$ when it reaches values higher than 0.25 (for reasons explained in the Results section, see Figure $7 \mathrm{~b}$ ). When $S_{e, p r o f}$ was below 0.25, there was a clear reduction in sap flow, which became even more pronounced with values below 0.18 . When $S_{e, p r o f}$ values were around $0.16, \mathrm{~F}_{d n c}$ became negligible, and NDVI reached its minimum ( 0.34 for $\mathrm{NDVI}_{\text {modis }}$ and $\left.0.26 \mathrm{NDVI}_{S 2}\right)$, indicating a minimum NDVI for the monitored Caatinga species. Although $\mathrm{F}_{d n c}$ was poorly correlated to water availability when $S_{e, p r o f}$ values were $>0.25$ (indicating that the lack of radiation is a stronger driver), values of $S_{e, p r o f}$ remained below 0.25 for more than $80 \%$ of the monitored period, indicating that for at least $80 \%$ of the year, water availability was the dominant environmental driver of transpiration. This dependence of $\mathrm{F}_{d n c}$ on $S_{e, p r o f}$ indirectly explains the high correlation between $F_{d n c}$ and NDVI, as shown in Table 4 , since NDVI also strongly depends on $S_{e, p r o f}$ (Figure $7 \mathrm{~b}$ ).

In the dry season, when $\mathrm{F}_{d n}$ was approaching 0 , for four of the monitored species (Figure 6) the timing difference seems to be due to differences in wood density, $W_{d}$. However, for the species with high $\mathrm{F}_{d n}$, this difference is subtle. As can be surmised from Figure 6, the order in which $\mathrm{F}_{d n}$ approached 0 was inversely correlated with the order of $W_{d}$ : C. leptophloeos $\left(0.28 \mathrm{~g} \cdot \mathrm{cm}^{-3}\right)$ at the end of April; A. pyrifolium $\left(0.54 \mathrm{~g} \cdot \mathrm{cm}^{-3}\right)$ at the end of June; A. colubrina $\left(0.59 \mathrm{~g} \cdot \mathrm{cm}^{-3}\right)$ in mid July; C. nordestinum $\left(0.66 \mathrm{~g} \cdot \mathrm{cm}^{-3}\right)$ in mid to late July. Although this study only compared the $W_{d}$ of four species, our results indicate that low $W_{d}$ is a limiting factor for these plants, particularly considering the duration in which 
they can maintain foliage, since the early senescence observed for low $W_{d}$ species may be part of the plant's water conservation strategy as is stomatal control, which ultimately prevents the plant from cavitation [15-17]. Thus, the high $W_{d}$ promoted by thick cell walls plays an important role in protecting plants from cavitation, allowing the plant to continue extracting water even from relatively dry soils.

Since $W_{d}$ is directly related to the capacity of Caatinga plant tissues to store water [3], species with higher wood densities, which have larger stores of water, may be able to survive extremely dry periods. Moreover, the species with the lowest $W_{d}, C$. leptophloeos has the shortest sap flow period (Figure 6) and exhibits a peculiar greenish photosynthetic bark [48], which increases plant survival during the dry season [49]. Unfortunately, our data set did not allow us to gather evidence of a higher leaf water potential maintained over a longer period for the species with lower wood density.

C. leptophloeos was not dominant in the monitoring plot and behaved differently, from a phenological perspective, from the other species: leaf flushing began earlier and occured at a slightly faster rate. This species also has a very early onset of senescence (Figure 6f), as was previously reported by [3] and attributed to the species low wood density and high water storage characteristics. Despite the fact that the high storage water capacity increases plant survival during dry periods, its low wood density suggests it cannot extract water from soils with very negative water potentials. Therefore, to avoid cavitation, this species shows an early EOS. Furthermore, it is expected that species with considerably different phenologies and low dominance will have a low correlation with the overall phenological timing of the plot-level vegetation. This explains the low correlations of C. leptophloeos $\mathrm{F}_{d n}$ with the vegetation indices, which reflects the entire plot (Table 4).

The GCC $_{n s}$ values of A. pyrifolium decreased considerably in the dry period but did not reach their minimum until the onset of the dry season, contrary to the drop in $\mathrm{F}_{d n}$ and its ranking with regards to $W_{d}$. However, low GCC values indicate a long leafless period, which was confirmed by the visual inspection of digital imagery and the negligible values of transpiration. The young green leaves of A. pyrifolium, with high photosynthetic and transpiration rates, were produced one month after the onset of the rainy season, unlike the other species in which leaf flushing began only a few days after the rains. Moreover, it is worth mentioning that the individuals monitored using GCC were not the same ones monitored with the sap flow sensors, despite the fact that they belong to the same species.

The index adjusted to the soil, $\mathrm{SAVI}_{S 2}$, showed higher EOS bias (-47 days), compared to $\mathrm{NDVI}_{S 2}$ (-42 days) (Table 5), but a considerable lower SOS bias (-18 days) than $\mathrm{NDVI}_{S 2}$ (-42 days). Moreover, $\mathrm{GCC}_{n s}$ presented a higher correlation with SAVI $\mathrm{S}_{S 2}(0.74)$ than $\mathrm{NDVI}_{S 2}$ (0.72) (Supplementary Materials, Table S2). Although the differences may seem small, taking into account that the dates for EOS and SOS extracted from GCC $_{n s}$ are the most realistic representation of phenology in this work (since they were confirmed with visual analysis), we can say that $\mathrm{SAVI}_{S_{2}}$ better represents phenology in terms of leaf presence. However, regarding plant water use, $\mathrm{SAVI}_{S 2}$ showed a lower correlation with $\mathrm{F}_{d n c}$, indicating that the best vegetation index representing phenology is not necessarily the best VI representing plant water use.

$\mathrm{F}_{d n c}$ exhibited a stronger linear relationship with NDVI derived from MODIS and Sentinel-2 ( $R^{2} 0.92$ and $R^{2} 0.88$, respectively) than the other indices (Table 4; Figure 7). A plausible explanation for the lower performance of the $\mathrm{NDVI}_{S 2}$ is that with an increase in the resolution, the pixel heterogeneity and number of pixels per image will increase, which means that the Sentinel-2 images will be noisier. Another explanation is that the MODIS algorithm has already undergone numerous revisions, while Sentinel-2 processing may not be mature enough. In the present work, the automatic cloud detection and cirrus correction filter offered by sen2core was not totally effective, requiring a subsequent visual analysis, suggesting that the algorithm still needs improvement. The last and most likely reason is that the higher temporal resolution of MODIS increases the chance of resulting in a better image composition; therefore, the lower temporal resolution of Sentinel-2 has 
a higher risk of yielding poor quality images, even when accounting for the filters and quality ratings.

Compared to the near-surface $\mathrm{GCC}_{n s}$, the $\mathrm{GCC}_{S 2}$ data show a stronger correlation with the sap flow data. Theoretically linked to leaf age, both GCC indices decrease when senescence occurs for all monitored species, as expected. However, GCC $_{n s}$ displayed a slight increase before the end of the dry season (Figure 6). This unexpected rise follows the first sporadic rains and produced a temporary disconnect with $\mathrm{F}_{d n}$ and soil water storage, causing the relatively poor correlations (Table 4). Other likely explanations for these lower performances include: signal contamination by shrub vegetation, wet/dry terrain, difficulty in selecting pixels, and even the wind causing leaf movements. However, an increase in GCC $_{n s}$ clearly signals the beginning of leaf flushing, thus it could be used in studies investigating when the growing season begins, the rate of leaf establishment, and how long the growing season lasts. Therefore, near-surface GCC data are important as it allows for individual monitoring of tree species.

Our results regarding the transition dates and water use indicate that the $\mathrm{NDVI}_{\text {modis }}$ provided the best fit and most reliable proxy for the community phenology, but both datasets performed well. The choice of VI is of paramount importance to understand the relation of phenology and plant water use at both the species and community levels [21]. Therefore, detection of the near remote phenology through the use of digital cameras (phenocams) can fill the gap between satellite and on-the-ground observations, improving the detection of which VI better represents the vegetation changes observed on the ground (see [21]). On the other hand, phenocam GCC also enhanced our understanding of the sap flow dynamics in individual plants. The fact that the decrease in sap flow is not coupled with the decrease in $\mathrm{GCC}_{n s}$ at the end of the rainy season in 2018 (Figure 6) indicates that the leaf drop of most species is preceded by the cessation of sap flow. As expected, both sap flow and $\mathrm{GCC}_{n s}$ remained low during the dry season. Nevertheless, while $\mathrm{GCC}_{n s}$ remained high and at approximately constant values after leaf flushing, the sap flow was variable during the 2018 rainy season. Regardless, the strong correlation between $\mathrm{F}_{d n c}$ and both NDVIs shows that the recorded phenological behaviour of the tree vegetation in the plot, as reflected by fluctuations in vegetation indices such as NDVI, represents the overall profile soil moisture conditions well and its effects on the canopy exchange processes for this Caatinga vegetation.

Our findings compare remote sensing products related to vegetation status at different temporal and spatial scales, with the aim to analyse the water use of Caatinga vegetation. Sentinel-2 and MODIS satellite products also provide data from various other spectral bands that have not been used in our analyses. Bands that could be used to generate other indices, for example, which could be explored with advanced statistical methods, and combined with in-situ data that are complementary to ours or with data from other satellite platforms. Therefore, our study addresses the hypotheses set out at the beginning of the paper, but points to paths in which future work could be further explored.

\section{Conclusions}

Given the hypotheses raised, we can conclude the following:

(1) Soil water availability explained the Caatinga phenology at an ecosystem level, but less so at the species level;

(2) Seasonal signals of vegetation indices GCC and NDVI derived from optical RS data collected for Caatinga vegetation were indeed strongly related to water use, as represented by the late-morning community level sap flow data. However, the individual GCC determined from proximal RS (phenocams) was poorly correlated to individual sap flow.

(3) The sap flow of the monitored species was entirely limited by soil water availability when relative saturation of the soil profile fell below 0.25 , a situation that occurred for more than $80 \%$ of the observed year. 
Our results provide meaningful information about the physiological responses of dry forests in the Caatinga area to environmental variables. They also show the ability of different scales of SR products in detecting variations in plant phenology, which is essential information to interpret and analyse the soil water availability and plant flux density. Moreover, our findings identified when to use SR data as a proxy for phenological and physiologal processes in the Caatinga vegetation.

Supplementary Materials: The following are available online at https://www.mdpi.com/2072-429 2/13/1/75/s1, Table S1: Soil characteristics estimated: $\theta_{s}, \theta_{f c}, \theta_{w p}, \theta_{r} ;$ the $\theta_{\max }$ and $\theta_{\min }$ observed for each monitored soil layer depth (in $\mathrm{cm}^{3} \mathrm{~cm}^{-3}$ ) and; the $\mathrm{r}^{2}$ of the Durner model versus observed water retention curve, for each layer, Figure S1: Scatter plot of measured individuals sapwood depth $(\mathrm{mm})$ and their respective DBH $(\mathrm{mm})$, Table S2: Pearson correlation table-near-surface GCC versus orbital VI. Figure S2: Community sap flow and phenological response: (A) Normalized sap flow for the plot community ( $\mathrm{F}_{d n c}$, dimensionless), $\mathrm{GCC}_{S 2}$ and $\mathrm{SAVI}_{S 2}$. (B) $\mathrm{F}_{d n c}, \mathrm{NDVI}_{\text {modis }}$ and $\mathrm{NDVI}_{S 2}$.

Author Contributions: Conceptualization, R.A.P. and L.D.S.B.; Formal analysis, R.A.P.; Funding acquisition, L.D.S.B.; Investigation, R.A.P., D.J.V., R.S. and L.D.S.B.; Methodology, R.A.P., D.M.R., L.P.C.M. and L.D.S.B.; Project administration, L.D.S.B.; Resources, E.S. and L.D.S.B.; Software, R.A.P., D.M.R. and R.S.; Supervision, L.D.S.B.; Validation, R.A.P., R.S., R.L.B.N. and A.V.; Writing-original draft, R.A.P. and L.D.S.B.; Writing-review \& editing, R.A.P., R.L.B.N., I.A.C.C., A.V., L.P.C.M., D.M.R. and T.S.K. All authors have read and agreed to the published version of the manuscript.

Funding: This study was financed by the São Paulo Research Foundation (FAPESP) grant \#2015/504885, by Coordenação de Aperfeiçoamento de Pessoal de Nível Superior-Brasil (CAPES)-Finance Code 001, and Newton Fund/NERC/FAPESP NE/N012488/1. A Verhoef and R Nobrega were supported by the Newton/NERC/FAPESP Nordeste project: NE/N012488/1. L.P.C.M. receives a research fellowship from the National Council for Scientific and Technological Development (CNPq). DMR receives a FAPESP fellowship (grant FAPESP \#2017/17380-1).

Acknowledgments: We thank the Government Company of Agricultural Research from the Semiarid (Embrapa semi-árido); the Academic Unit of Serra Talhada (UAST); the Academic Unit of Garanhuns (UAG) from Rural Federal University of Pernambuco (UFRPE); the National Observatory of Water and Carbon Dynamics in the Caatinga Biome-NOWCDCB, for, among others, allowing the use of tools, academic installations, providing technical assistance and labour to carry out the installation of sensors and maintenance of equipment; Luciano Paganucci de Queiroz and his team, for leading the work of the Herbarium at State University of Feira de Santana in the species identification; Jonathan Lloyd for assisting in the management of financial and human resources and for his contributions in developing the methods.

Conflicts of Interest: The authors declare no conflict of interest.

\section{References}

1. Pugnaire, F.I.; Morillo, J.A.; Peñuelas, J.; Reich, P.B.; Bardgett, R.D.; Gaxiola, A.; Wardle, D.A.; van der Putten, W.H. Climate change effects on plant-soil feedbacks and consequences for biodiversity and functioning of terrestrial ecosystems. Sci. Adv. 2019, 5, eaaz1834. [CrossRef] [PubMed]

2. Francesconi, W.; Srinivasan, R.; Pérez-Miñana, E.; Willcock, S.P.; Quintero, M. Using the Soil and Water Assessment Tool (SWAT) to model ecosystem services: A systematic review. J. Hydrol. 2016, 535, 625-636. [CrossRef]

3. Lima, A.L.A.; de Sá Barretto Sampaio, E.V.; de Castro, C.C.; Rodal, M.J.N.; Antonino, A.C.D.; de Melo, A.L. Do the phenology and functional stem attributes of woody species allow for the identification of functional groups in the semiarid region of Brazil? Trees 2012, 26, 1605-1616. [CrossRef]

4. Alberton, B.; da Silva Torres, R.; Silva, T.S.F.; Rocha, H.; Moura, M.S.B.; Morellato, L. Leafing Patterns and Drivers across Seasonally Dry Tropical Communities. Remote Sens. 2019, 11, 2267. [CrossRef]

5. Murphy, P.G.; Lugo, A.E. Ecology of Tropical Dry Forest. Annu. Rev. Ecol. Syst. 1986, 17, 67-88. [CrossRef]

6. Särkinen, T.; Iganci, J.R.; Linares-Palomino, R.; Simon, M.F.; Prado, D.E. Forgotten forests-issues and prospects in biome mapping using Seasonally Dry Tropical Forests as a case study. BMC Ecol. 2011, 11. [CrossRef]

7. Pennington, R.T.; Lavin, M.; Oliveira-Filho, A. Woody Plant Diversity, Evolution, and Ecology in the Tropics: Perspectives from Seasonally Dry Tropical Forests. Annu. Rev. Ecol. Evol. Syst. 2009, 40, 437-457. [CrossRef]

8. Pennington, R.T.; Lehmann, C.E.; Rowland, L.M. Tropical savannas and dry forests. Curr. Biol. 2018, 28, R541-R545. [CrossRef]

9. Machado, I.C.S.; Barros, L.M.; Sampaio, E.V.S.B. Phenology of Caatinga Species at Serra Talhada, PE, Northeastern Brazil. Biotropica 1997, 29, 57-68. [CrossRef] 
10. de Souza, M.J.N.; de Oliveira, J.G.B.; Lins, R.C.; Jatobá, L. Overview of the Brazilian caatinga. Rev. CiêNcia TróPico 1992, 20, 173-198.

11. Sampaio, E.V. Overview of the Brazilian caatinga. In Seasonally Dry Tropical Forests; Cambridge University Press: Cambridge, UK, 1995; pp. 35-63.

12. Lemos, J.R.; Rodal, M.J.N. Fitossociologia do componente lenhoso de um trecho da vegetação de caatinga no Parque Nacional Serra da Capivara, Piauí, Brasil. Acta Bot. Bras. 2002, 16, 23-42. [CrossRef]

13. Reddy, S. Climatic classification: the semi-arid tropics and its environment-A review. Pesquisa Agro 1983, 18, 823-847.

14. Lima, A.L.A.; Rodal, M.J.N. Phenology and wood density of plants growing in the semi-arid region of northeastern Brazil. J. Arid. Environ. 2010, 74, 1363-1373. [CrossRef]

15. Sobrado, M.A. Trade-off between water transport efficiency and leaf life-span in a tropical dry forest. Oecologia 1993, 96, 19-23. [CrossRef] [PubMed]

16. Stratton, L.; Goldstein, G.; Meinzer, F.C. Stem water storage capacity and efficiency of water transport: their functional significance in a Hawaiian dry forest. Plant Cell Environ. 2000, 23, 99-106. [CrossRef]

17. Hacke, U.G.; Sperry, J.S.; Pockman, W.T.; Davis, S.D.; McCulloh, K.A. Trends in wood density and structure are linked to prevention of xylem implosion by negative pressure. Oecologia 2001, 126, 457-461. [CrossRef]

18. Reich, P.B.; Wright, I.J.; Cavender-Bares, J.; Craine, J.M.; Oleksyn, J.; Westoby, M.; Walters, M.B. The Evolution of Plant Functional Variation: Traits, Spectra, and Strategies. Int. J. Plant Sci. 2003, 164, S143-S164. [CrossRef]

19. Swenson, N.G.; Enquist, B.J. Ecological and evolutionary determinants of a key plant functional trait: Wood density and its community-wide variation across latitude and elevation. Am. J. Bot. 2007, 94, 451-459. [CrossRef]

20. Chave, J.; Coomes, D.; Jansen, S.; Lewis, S.L.; Swenson, N.G.; Zanne, A.E. Towards a worldwide wood economics spectrum. Ecol. Lett. 2009, 12, 351-366. [CrossRef]

21. Richardson, A.D.; Hufkens, K.; Milliman, T.; Aubrecht, D.M.; Chen, M.; Gray, J.M.; Johnston, M.R.; Keenan, T.F.; Klosterman, S.T.; Kosmala, M.; et al. Tracking vegetation phenology across diverse North American biomes using PhenoCam imagery. Sci. Data 2018, 5. [CrossRef]

22. Ferreira, T.R.; Silva, B.B.D.; Moura, M.S.B.D.; Verhoef, A.; Nóbrega, R.L. The use of remote sensing for reliable estimation of net radiation and its components: A case study for contrasting land covers in an agricultural hotspot of the Brazilian semiarid region. Agric. For. Meteorol. 2020, 291, 108052. [CrossRef]

23. de Queiroga Miranda, R.; Nóbrega, R.L.B.; de Moura, M.S.B.; Raghavan, S.; Galvíncio, J.D. Realistic and simplified models of plant and leaf area indices for a seasonally dry tropical forest. Int. J. Appl. Earth Obs. Geoinf. 2020, 85, 101992. [CrossRef]

24. Coaguila, D.N.; Hernandez, F.B.T.; de Teixeira, C.A.H.; Franco, R.A.M.; Leivas, J.F. Water productivity using SAFER-Simple Algorithm for Evapotranspiration Retrieving in watershed. Rev. Bras. Eng. Agric. Ambient. 2017, 21, 524-529. [CrossRef]

25. de C. Teixeira, A.H. Determining Regional Actual Evapotranspiration of Irrigated Crops and Natural Vegetation in the São Francisco River Basin (Brazil) Using Remote Sensing and Penman-Monteith Equation. Remote Sens. 2010, 2, 1287-1319. [CrossRef]

26. Alberton, B.; Torres, R.; Cancian, L.F.; Borges, B.D.; Almeida, J.; Mariano, G.C.; dos Santos, J.; Morellato, L.P.C. Introducing digital cameras to monitor plant phenology in the tropics: Applications for conservation. Perspect. Ecol. Conserv. 2017, 15, 82-90. [CrossRef]

27. Kandasamy, S.; Baret, F.; Verger, A.; Neveux, P.; Weiss, M. A comparison of methods for smoothing and gap filling time series of remote sensing observations: Application to MODIS LAI products. Biogeosci. Discuss. 2012, 9, 17053-17097. [CrossRef]

28. Ren, R.; von der Crone, J.; Horton, R.; Liu, G.; Steppe, K. An improved single probe method for sap flow measurements using finite heating duration. Agric. For. Meteorol. 2020, 280, 107788. [CrossRef]

29. Goldstein, G.; Meinzer, F.C.; Bucci, S.J.; Scholz, F.G.; Franco, A.C.; Hoffmann, W.A. Water economy of Neotropical savanna trees: Six paradigms revisited. Tree Physiol. 2008, 28, 395-404. [CrossRef]

30. Butz, P.; Hölscher, D.; Cueva, E.; Graefe, S. Tree Water Use Patterns as Influenced by Phenology in a Dry Forest of Southern Ecuador. Front. Plant Sci. 2018, 9. [CrossRef]

31. Granier, A. Une nouvelle méthode pour la mesure du flux de sève brute dans le tronc des arbres. Ann. Des Sci. For. 1985, 42, 193-200. [CrossRef]

32. Granier, A. Evaluation of transpiration in a Douglas-fir stand by means of sap flow measurements. Tree Physiol. 1987, 3, 309-319. [CrossRef] [PubMed]

33. Ping, L.; Layrent, U.; Ping, Z. Granier's thermal dissipation probe (TDP) method for measuring sap flow in trees: Theory and practice. Acta Bot. Sin. 2004, 46, 631-646.

34. Pasqualotto, G.; Carraro, V.; Menardi, R.; Anfodillo, T. Calibration of Granier-Type (TDP) Sap Flow Probes by a High Precision Electronic Potometer. Sensors 2019, 19, 2419. [CrossRef]

35. Grossiord, C.; Christoffersen, B.; Alonso-Rodríguez, A.M.; Anderson-Teixeira, K.; Asbjornsen, H.; Aparecido, L.M.T.; Berry, Z.C.; Baraloto, C.; Bonal, D.; Borrego, I.; et al. Precipitation mediates sap flux sensitivity to evaporative demand in the neotropics. Oecologia 2019, 191, 519-530. [CrossRef]

36. Soil-Survey-Staff. Soil Taxonomy: A Basic System of Soil Classification of Making and Interpreting Soil Surveys; USDA. Agriculture Handbook, 436; Natural Resources Conservation Service: Washington, DC, USA, 1999; p. 869.

37. Jacomine, P.K.T.; Cavalcanti, A.C.; Burgos, N.; Pesso, S.C.P.; Silveira, C.O. Levantamento Exploratório-Reconhecimento de Solos do Estado de Pernambuco; Boletim Técnico, 26-Pedologia, 14 2V; EMBRAPA-Divisão de Pesquisa Pedológica: Recife, Brazil, 1973. 
38. Kottek, M.; Grieser, J.; Beck, C.; Rudolf, B.; Rubel, F. World Map of the Köppen-Geiger climate classification updated. Meteorol. Z. 2006, 15, 259-263. [CrossRef]

39. Rubel, F.; Brugger, K.; Haslinger, K.; Auer, I. The climate of the European Alps: Shift of very high resolution Köppen-Geiger climate zones 1800-2100. Meteorol. Z. 2017, 26, 115-125. [CrossRef]

40. Climate-Data.org. Clima Serra Talhada. Available online: https://pt.climate-data.org/america-do-sul/brasil/pernambuco/ serra-talhada-42488/ (accessed on 16 September 2019).

41. Moonlight, P.; Banda, R.K.; Phillips, O.; Dexter, K.; Pennington, R.; Baker, T.; de Lima, H.C.; Fajardo, L.; González-M, R.; Linares-Palomino, R.; et al. Expanding tropical forest monitoring into Dry Forests: The DRYFLOR protocol for permanent plots. Plants People Planet 2020. [CrossRef]

42. Vajsová, B.; Fasbender, D.; Wirnhardt, C.; Lemajic, S.; Devos, W. Assessing Spatial Limits of Sentinel-2 Data on Arable Crops in the Context of Checks by Monitoring. Remote Sens. 2020, 12, 2195. [CrossRef]

43. Yan, L.; Roy, D.; Li, Z.; Zhang, H.; Huang, H. Sentinel-2A multi-temporal misregistration characterization and an orbit-based sub-pixel registration methodology. Remote Sens. Environ. 2018, 215, 495-506. [CrossRef]

44. da Silva, P.F.; Lima, J.R.D.S.; Antonino, A.C.D.; Souza, R.; de Souza, E.S.; Silva, J.R.I.; Alves, E.M. Seasonal patterns of carbon dioxide, water and energy fluxes over the Caatinga and grassland in the semi-arid region of Brazil. J. Arid. Environ. 2017, 147, 71-82. [CrossRef]

45. Costa, M.H.; Biajoli, M.C.; Sanches, L.; Malhado, A.C.M.; Hutyra, L.R.; da Rocha, H.R.; Aguiar, R.G.; de Araújo, A.C. Atmospheric versus vegetation controls of Amazonian tropical rain forest evapotranspiration: Are the wet and seasonally dry rain forests any different? J. Geophys. Res. 2010, 115. [CrossRef]

46. de Oliveira, C.C.; Zandavalli, R.B.; Lima, A.L.A.; Rodal, M.J.N. Functional groups of woody species in semi-arid regions at low latitudes. Austral Ecol. 2014, 40, 40-49. [CrossRef]

47. Tetens, O. Uber einige meteorologische Begriffe. Z. Geophys. 1930, 6, 297-309.

48. Killeen, T.J.; Jardim, A.; Mamani, F.; Rojas, N. Diversity, composition and structure of a tropical semideciduous forest in the Chiquitanía region of Santa Cruz, Bolivia. J. Trop. Ecol. 1998, 14, 803-827. [CrossRef]

49. Mahr, D. Commiphora: An Introduction to the Genus. Cactus Succul. J. 2012, 84, 140-154. [CrossRef] 